\title{
The value of inflammatory markers in diagnosing acute appendicitis in pregnant patients
}

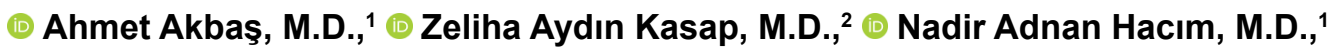

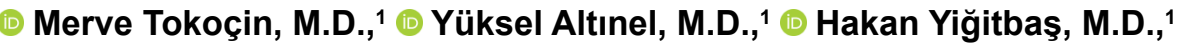 \\ (1) Serhat Meriç, M.D., ${ }^{1}$ ๑ Bakiye Okumuş, M.D. ${ }^{3}$
}

\begin{abstract}
${ }^{1}$ Department of General Surgery, University of Health Sciences, Bağcılar Training and Research Hospital, İstanbul-Turkey ${ }^{2}$ Department Biostatistics and Medical Informatics, Karadeniz Technical University Faculty of Medicine, Trabzon-Turkey ${ }^{3}$ Department of Obstetrics and Gynecology, İstinye University Faculty of Medicine, İstanbul-Turkey
\end{abstract}

\begin{abstract}
BACKGROUND: Acute appendicitis (AA) is the most common extra-obstetric condition requiring surgery during pregnancy. AA diagnosis is made by laboratory tests along with anamnesis and physical examination findings. Due to the physiological and anatomical changes during the pregnancy, AA diagnosis is more challenging in pregnant women compared to non-pregnant patients. The present study evaluated the significance of white blood cell counts (WBC), neutrophil-to-lymphocyte ratio (NLR), C-reactive protein/albumin ratio (CAR) and lymphocyte-to-C-reactive protein ratio (LCR) to diagnose acute appendicitis during pregnancy.

METHODS: Pregnant patients admitted to General Surgery Inpatient Clinic with AA pre-diagnosis in September 20I5-December 2019 period were screened using International Statistical Classification of Diseases and Related Health Problems- 10 (ICD- I0) diagnosis code $(K 35=$ acute appendicitis, $Z 33=$ pregnancy), and AA patients were identified retrospectively. The patients were divided into two groups. The Group I included the patients who had appendectomy due to AA and had a suppurative appendicitis diagnosis based on the pathological evaluation. On the other hand, Group II had the patients admitted as an inpatient with AA pre-diagnosis, but discharged from the hospital with full recovery without operation. Group III, i.e., the control group, on the other hand, was constituted by 32 randomly and prospectively recruited healthy pregnant women who were willing to participate in the study and who had matching study criteria among the patients followed in Obstetrics and Gynecology outpatient clinic of our hospital.
\end{abstract}

RESULTS: This study included 96 pregnant women with an average age of $29.20 \pm 4.47$ years ( 32 healthy pregnant women, 32 pregnant women followed for acute abdominal observation and 32 pregnant women who underwent appendectomy). Of these patients, three cases who turned out not to have suppurative appendicitis (negative appendectomy) and two cases found to have perforated appendicitis based on intraoperative and histopathological evaluations were excluded from this study. The results showed that Group I patients had significantly higher WBC $(p=0.00 \mathrm{I}), C A R(p=0.00 \mathrm{I})$ and NLR $(p=0.00 \mathrm{I})$, but significantly lower $L C R$ values $(p=0.00 \mathrm{I})$ compared to the Groups II and III. Besides, based on logistic regression analysis, it was revealed that higher WBC, CAR and NLR values and lower $L C R$ values were independent variables that could be used for the diagnosis of $A A$ in pregnant women.

CONCLUSION: Considering WBC, NLR, CAR and LCR parameters in addition to medical history, physical examination and imaging techniques could help clinicians diagnose acute appendicitis in pregnant women.

Keywords: Acute appendicitis; CRP albumin ratio; lymphocyte; neutrophil; pregnancy.

\section{INTRODUCTION}

The most common cause of non-obstetric surgery during pregnancy is acute appendicitis (AA), and its incidence rate is similar to that of non-pregnant patients. ${ }^{[1]}$ The diagnosis of AA is made based on the patient's anamnesis and physical

Cite this article as: Akbaş A, Aydın Kasap Z, Hacım NA, Tokoçin M, Altınel Y, Yiğitbaş H, et al. The value of inflammatory markers in diagnosing acute appendicitis in pregnant patients. Ulus Travma Acil Cerrahi Derg 2020;26:769-776.

Address for correspondence: Ahmet Akbaş, M.D.

Sağlık Bilimleri Üniversitesi, İstanbul Bagcılar Eğitim ve Araştırma Hastanesi, Genel Cerrahi Kliniği, ìstanbul, Turkey

Tel: +90 212 - 4404000 E-mail: draakbas@hotmail.com

Ulus Travma Acil Cerrahi Derg 2020;26(5):769-776 DOI: 10.14744/tjtes.2020.03456 Submitted: 03.02.2020 Accepted: 23.07.2020 Online: 09.09.2020

Copyright 2020 Turkish Association of Trauma and Emergency Surgery 
examination findings accompanied by laboratory tests. Due to physiological and anatomical changes during pregnancy, the diagnosis of $A A$ is more difficult than in non-pregnant patients. In addition, the lack of pathognomonic signs and findings, and poor predictive value of the relevant laboratory tests make the diagnosis of AA difficult in pregnant patients. ${ }^{[2]}$ This could be life-threatening for the mother and fetus. ${ }^{[3]}$

There is no specific laboratory parameter specific to AA diagnosis, but white blood cell count (WBC) and C-reactive protein (CRP) are commonly used for this purpose. However, physiological leukocytosis occurs during pregnancy, and WBC and CRP levels increase in the late weeks of gestation. [4,5] Therefore, the use of WBC and CRP parameters alone could be misleading in the diagnosis of AA during pregnancy. ${ }^{[6]}$ Neutrophil white blood cells are a major part of the immune system. Mast cells, epithelial cells and neutrophils regulated by macrophages also play important roles in inflammatory events. The role of lymphocytes in the development of inflammation and infection is well-known. ${ }^{[7]}$ There have been recent reports about using the ratios of these inflammatory markers, such as neutrophil-to-lymphocyte ratio (NLR) and lymphocyte-to-C-reactive protein ratio (LCR), for early inflammation markers in AA diagnosis. ${ }^{[4,8]}$

AA causes the initiation of an inflammatory process secondary to bacterial infection in the body, resulting in the formation of an acute phase response by the body against the pathological agent. Proteins whose serum or plasma levels increase or decrease during this period are called acute phase proteins (APP). APP synthesis takes place in the liver due to cytokines released from tissue macrophages, and they nonspecifically reflect the presence and severity of inflammation. [9] The proteins whose synthesis increase depending upon AFY are referred to positive acute phase reactant while those whose synthesis decrease are termed negative acute phase reactant. The amount of CRP increases in the acute phase response secondary to inflammation in the organism, while the amount of albumin decreases. ${ }^{[10,11]} \mathrm{CRP} /$ albumin ratio (CAR) is a parameter that has been used recently, and there are not many studies about this parameter in the literature. Some studies indicated that elevated CAR values indicate the severity of infection-related inflammation. ${ }^{\left[{ }^{\prime I}\right]}$ Among them are the studies mentioning that high CAR values could be used as a marker to determine the severity of infection in acute exacerbations of Crohn's disease. ${ }^{[10,12]}$ Similarly, Goulart et al. [13] found that high CAR values could be used as a marker to determine surgical site infection during the postoperative period in patients operated due to colorectal cancer.

Although ultrasonography (USG) is the most frequently used sonographic method in the diagnosis of AA, it may not meet the expectations due to anatomical changes observed during pregnancy. The use of Magnetic Resonance (MR) is limited since it is expensive, is not easily accessible and takes a long time for the examination. On the other hand, the use of
Computed Tomography (CT) is restricted due to its ionizing radiation. ${ }^{[6]}$ In the present study, we aimed to draw attention to the importance of using easily available, cost-effective inflammatory markers that could help physicians in the evaluation of patients with suspected acute appendicitis.

\section{MATERIALS AND METHODS}

After this study was approved by the ethical board of İstanbul Bağcılar Training and Research Hospital, pregnant patients admitted to General Surgery Inpatient Clinic of our hospital with AA pre-diagnosis in September 2015-December 2019 period were screened online in the hospital database system using International Statistical Classification of Diseases and Related Health Problems-I0 (ICD-I0) diagnosis code (K35= acute appendicitis, Z33= pregnancy), and AA patients were identified retrospectively. The patients were divided into two groups. The Group I included the patients who underwent appendectomy due to AA and had a suppurative appendicitis diagnosis based on pathological evaluation, while Group II had the patients who were admitted as an inpatient with AA pre-diagnosis, but discharged from the hospital with full recovery without being operated. Control group, i.e., the Group III, on the other hand, included 32 randomly and prospectively recruited healthy pregnant women who were willing to participate in the study and had matching study criteria among the patients monitored in Obstetrics and Gynecology outpatient clinic of our hospital. The individuals for whom laboratory parameters were not available, individuals who had hematological impairment, chronic liver or kidney disease, chronic obstructive pulmonary disease, asthma, any viral or bacterial infection, cancer or autoimmune disease, alcohol or tobacco use, individuals who were operated but did not have suppurative appendicitis based on histopathological findings (who had perforated appendicitis or negative appendectomy patients) and the patients with missing records were excluded.

Hemogram tests were performed on blood samples obtained from the venous system collected into ethylene diamine tetra acetic acid tubes. Blood samples for albumin and CRP were taken into serum tubes, with increased silica act clot activator, silicone-coated interior. As hemogram, albumin and CRP values, the assays performed within 24 hours of the patient's initial application were used. In case of the multiple analyses, the first analysis was taken into account. The white blood cell, neutrophil and lymphocyte values were taken from hemograms.

NLR value was calculated as the neutrophil/lymphocyte ratio, while LCR value was calculated as lymphocyte/CRP, and CAR was calculated as the CRP/albumin ratio. Hemogram testing parameters were measured using Abbott Cell-Dyn $3700 \mathrm{He}$ matology Analyzer, Abbott Diagnostics, USA, while biochemistry tests were carried out using Beckman Coulter AU 5800 Chemistry analyzer, USA; albumin was analyzed with brome 
cresol purple method, and CRP was studied as an immunoturbidimetric assay. The limits of the reference intervals were as follows: leukocyte counts (WBC): 4600-10200/ $\mu \mathrm{L}$, neutrophil: $2.0-6.9 \times 10^{3} / \mu \mathrm{L}$; lymphocyte: $0.6-3.4 \times 10^{3} / \mu \mathrm{L} ; \mathrm{CRP}$ : $0-5 \mathrm{mg} / \mathrm{l}$; albumin: $3.5-5.4 \mathrm{mg} / \mathrm{l})$.

All statistical analyses were performed using IBM SPSS Statistics 22.0 software. The Kolmogorov Smirnov test was used to determine the normality of the distribution, and the Levene test was used to determine the homogeneity of variances among the groups. ANOVA and Kruskal Wallis tests were used to compare the means of the variables. Bonferroni and Tamhane's T2 tests were used as post hoc analysis. Receiver Operating Characteristic (ROC) curve and Area under the Curve (AUC) was calculated for diagnostic performance and to evaluate biomarkers' ability for classifying disease status. The Likelihood Ratios and Youden Index were calculated with the help of sensitivity and specificity values in order to decide the most appropriate cut-off points using MS Excel software. A multinomial logistic regression test was used to define the cause-effect relationship of the categorical response variable with explanatory variables. Quantitative data were expressed as mean \pm standard deviation. Nonparametric test results were expressed as median (maximum-minimum). Data were analyzed at a $95 \%$ confidence interval, and statistical significance was set at $p<0.05$.

\section{RESULTS}

This study included 96 pregnant patients with an average age of $29.20 \pm 4.47$ years (32 healthy pregnant women, 32 pregnant women under acute abdominal observation and 32 pregnant women who underwent appendectomy). Of these patients, three cases that did not have suppurative appendicitis based on surgery and histopathological findings (negative appendectomy) and two patients with perforated appendicitis were excluded from this study.

There was no significant difference among the groups concerning mean age $(p=0.190)$ and gestational week $(p=0.235)$. In addition, it was found that Group I patients had a mean WBC value of $14.09 \pm 3.60 / \mathrm{m}^{\mathrm{m} 3}$, a median CAR value of 10.93 (76.18-I.43), a median NLR value of 6.00 (I I.04-I.39) and a median LCR value of 0.05 (0.004-0.356), while Group II and III had mean WBC values of $9.66 \pm 2.84 / \mathrm{mm}^{3}$ and $10.68 \pm 2.32 / \mathrm{mm}^{3}$, median CAR values of $2.13(30.60-0.36)$ and 0.30 (2.13-0.04), median NLR values of 3.29 (6.9I-0.97) and 3.69 (I7.22 -0.75), and median LCR values of 0.23 $(0.0 \mathrm{I}-\mathrm{I} .40)$ and $2,0 \mathrm{I}(0.38-\mathrm{I}$ I.50), respectively. Thus, Group I had significantly higher WBC, CAR and NLR $(p<0.0$ I) but significantly lower LCR values compared to Group II and III $(p=0.01)$ (Table I).

Based on the multivariate logistic regression analysis, high WBC level (OR:I.45; 95\% Cl:I.I6-I.8I; $p=0.001$ ), high CAR level (OR:I3.826; 95\% Cl:4.30-44.45; $p=0.001$ ), high NLR level (OR:I.34; 95\% Cl:I.0I-I.78; $p=0.046)$ and low LCR level (OR:0.00I; 95\% Cl:3.642-0.00I; $p=0.001$ ) were independent variables for AA diagnosis in pregnant patients (Table 2).

In ROC curve analyses of these independent variables, AUC was above 0.600 for WBC, CAR, NLR and LCR (Fig. I). When a cutoff value of $>11.965 / \mathrm{mm}^{3}$ was used for WBC, the sensitivity was $77 \%$ and the specificity was $81 \%$ (accuracy rate $79 \%, A \cup C \pm S E=0.828 \pm 0.055$ and $p<0.001$ ) for $A A$ diagnosis. For $C A R$ variable to predict $A A$ diagnosis, the sensitivity was $96 \%$ and the specificity was $80 \%$ (accuracy rate $88 \%, A \cup C \pm S E=0.917 \pm 0.028, p<0.001$ ) using a cutoff value of $>2.473$. For NLR, the sensitivity was $68 \%$ and the specificity was $86 \%$ (accuracy rate $77 \%$, AUC \pm SE $=0.781 \pm 0.065$

Table I. Gestational age and hemogram parameters of the study groups

\begin{tabular}{|c|c|c|c|c|}
\hline & $\begin{array}{c}\text { Appendectomy } \\
\text { (Group I) }(n=27)\end{array}$ & $\begin{array}{c}\text { Acute abdominal } \\
\text { observation } \\
\text { (Group II) }(n=32)\end{array}$ & $\begin{array}{l}\text { Healthy pregnant } \\
\text { women } \\
\text { (Group III) }(n=32)\end{array}$ & $\mathbf{p}$ \\
\hline Age* & $27.45 \pm 4.76$ & $29.44 \pm 6.385$ & $30.19 \pm 4.782$ & $0.190^{* * * *}$ \\
\hline Gestational week $^{*}$ & $23.51 \pm 6.35$ & $21.18 \pm 6.27$ & $24.43 \pm 7.32$ & $0.235^{* * * k}$ \\
\hline $\mathrm{WBC}^{*}\left(/ \mathrm{mm}^{3}\right)$ & $14.09 \pm 3.60$ & $9.66 \pm 2.84$ & $10.68 \pm 2.32$ & $\begin{array}{c}<0.01 \\
\left(0.000^{* * *+k}\right)\end{array}$ \\
\hline $\mathrm{CAR}^{* *}$ & $10.93(76.18-1.43)$ & $2.13(30.60-0.36)$ & $0.30(2.13-0.04)$ & $\begin{array}{c}<0.01 \\
\left(0.000^{* * * * * *}\right)\end{array}$ \\
\hline$N^{\prime} R^{* *}$ & $6(11.04-1.39)$ & $3.29(6.91-0.97)$ & $3.69(17.22-0.75)$ & $\begin{array}{c}<0.01 \\
\left(0.000^{* * * * *)}\right.\end{array}$ \\
\hline LCR & $0.05(0.004-0.356)$ & $0.23(0.01-1.40)$ & 2,01 (0.38-II.50) & $\begin{array}{c}<0.01 \\
\left(0.000^{* * * * *}\right)\end{array}$ \\
\hline
\end{tabular}


Table 2. Results of the multinomial logistic regression analysis of white blood cell count, neutrophil-to-lymphocyte ratio, CRP/ albumin ratio and lymphocyte-to-CRP ratio to determine independent predictors of acute appendicitis in pregnant women

\begin{tabular}{lcccc}
\hline Independent variables & B \pm SE & P & Odds Ratio & 95\% Cl \\
\hline White blood cell count & $0.37 \pm 0.1 I$ & $<0.001$ & 1.45 & $1.16-1.8 \mathrm{I}$ \\
Neutrophil-to-lymphocyte ratio & $0.29 \pm 0.145$ & 0.046 & 1.34 & $1.01-1.78$ \\
Lymphocyte-to-CRP ratio & $-1.07 \pm 0.27$ & $<0.001$ & 0.342 & $0.203-0.577$ \\
CRP/Albumin ratio & $2.63 \pm 0.60$ & $<0.001$ & 13.826 & $4.30-44.45$ \\
Dependent variable: groups Nagelkerke $\mathrm{R}^{2}=0.808$ & $\mathrm{P}<0.001$ & Predicted $(\%)=83$ & \\
\hline
\end{tabular}

Multinomial logistic regression. B: The set of coefficients estimated for the model; Cl: Confidence interval; SE: Standard error; CRP: C-reactive protein.

Table 3. The results of ROC analysis

\begin{tabular}{|c|c|c|c|c|c|c|}
\hline Parameter & Cut-off values & Accuracy rate (\%) & Sensitivity (\%) & Specificity (\%) & $A U C \pm S E$ & $\mathbf{p}$ \\
\hline WBC & $>11.965$ & 0.79 & 0.77 & 0.81 & $0.828 \pm 0.055$ & $<0.001$ \\
\hline CAR & $>2.473$ & 0.88 & 0.96 & 0.80 & $0.917 \pm 0.028$ & $<0.001$ \\
\hline NLR & $>5.025$ & 0.77 & 0.68 & 0.86 & $0.78 I \pm 0.065$ & $<0.001$ \\
\hline LCR & $<0.127$ & 0.81 & 0.73 & 0.89 & $0.895 \pm 0.033$ & $<0.001$ \\
\hline
\end{tabular}

AUC: Area under the receiver operating characteristic curve; SE: Standard error; WBC: White blood cells. CAR: CRP/Albumin ratio; NLR: Neutrophil-to-lymphocyte ratio; LCR: Lymphocyte-to-CRP ratio.

and $\mathrm{p}<0.00 \mathrm{I})$ for the prediction of AA diagnosis when a cutoff value of $>5.025$ was used. When a cutoff value of $<0.127$ was used for LCR to predict AA diagnosis, the sensitivity was $73 \%$ and the specificity was $89 \%$ (accuracy rate $81 \%$, $A U C \pm S E=0.895 \pm 0.033, p<0.001)$. Proposed cutoff values and performance characteristics for these variables were shown in Table 3.

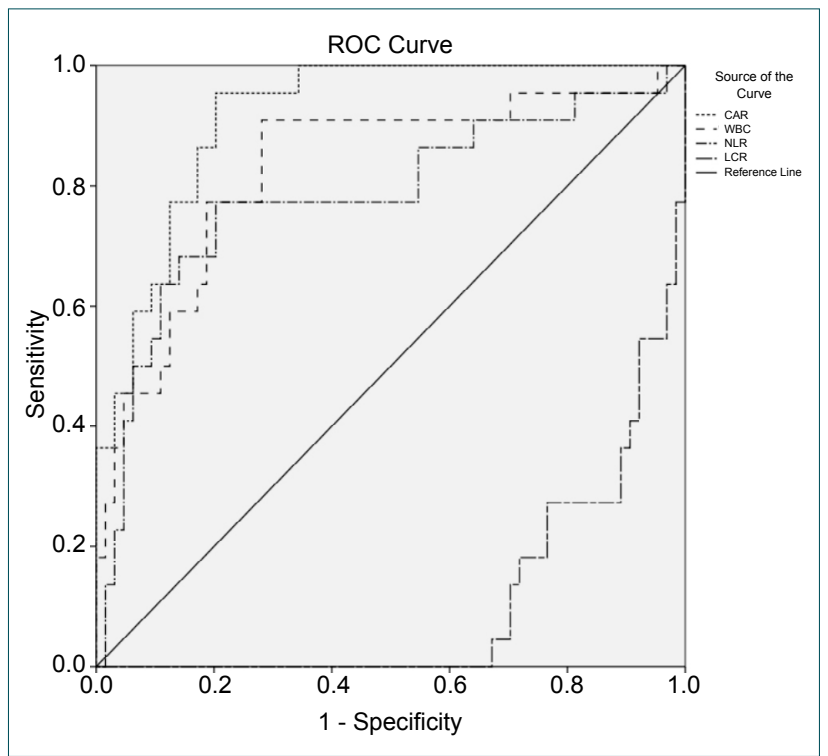

Figure 1. Receiver operating characteristic (ROC) curve analyses of significant parameters for the diagnosis of acute appendicitis: CAR: CRP/Albumin ratio; WBC: White blood cell count; NLR: Neutrophil-to-lymphocyte ratio; LCR: Lymphocyte-to-CRP ratio.

\section{DISCUSSION}

AA is among the most common causes of emergency surgery in pregnant patients. Physical examination and anamnesis are important in diagnosing AA. There are difficulties in AA diagnosis due to physiological and anatomical changes observed during pregnancy and due to the restrictions on the use of radiological methods. This increases the importance of using parameters involving acute phase reactants secondary to an inflammatory reaction in the body. In the present study, we found that inflammatory parameters, such as WBC, NLR, CAR, and LCR, could be considered to be statistically significant in AA diagnosis for pregnant patients.

WBC is a highly cost-effective and easily accessible laboratory parameter that is widely used in the diagnosis of AA. Elevated $W B C$ level is not a pathognomonic finding in patients with AA, but is used as an auxiliary parameter for AA diagnosis. ${ }^{[14]}$ Elevated WBC levels in peripheral blood are used as an acute phase reactants secondary to inflammation. ${ }^{[15]}$ Keskek et al. ${ }^{[15]}$ and Panagiotopoulou et al. ${ }^{[16]}$ reported that the WBC value of patients with AA was higher than the normal population. Yazar et al., ${ }^{[4]}$ on the other hand, found that the average WBC value was $10.762 \pm 1.513 / \mathrm{mm}^{3}$ in healthy pregnant women and $13.768 \pm 3.443 / \mathrm{mm}^{3}$ in patients undergoing an appendectomy. Yilmaz et al. ${ }^{[1]}$ reported an average WBC value of $12.702 \pm 4.180 / \mathrm{mm}^{3}$ in pregnant women who were operated due to $\mathrm{AA}$. In the present study, the average WBC value in healthy pregnant women was $10.680 \pm 2.32$ / $\mathrm{mm}^{3}$, which was $14.090 \pm 3.60 / \mathrm{mm}^{3}$ in pregnant patients op- 
erated due to AA. According to these results, WBC value was significantly higher in patients who were operated for AA compared to healthy pregnant women and pregnant women under acute abdominal observation (Table I). Based on the multivariate logistic analysis (multinomial logistic regression), WBC was found to be an independent risk factor for the diagnosis of AA in pregnant patients (Table 2). Previous studies reported sensitivity levels of 73.0-97.8\%, specificity levels of $52.0-55.7 \%$, PPV levels of $42.0-91.3 \%$, and NPV levels of 25.2-82.0\% for WBC in AA diagnosis. ${ }^{[14]}$ Such large sensitivity and specificity ranges could be due to the different cut-off values used in the diagnosis of AA. For example, Keskek et al. ${ }^{[15]}$ reported a cut-off value of $10.500 / \mathrm{mm}^{3}$, while Körner et al. ${ }^{[18]}$ mentioned a value of $12.300 / \mathrm{mm}^{3}$. Yazar et al. ${ }^{[4]}$ calculated the sensitivity as $57.1 \%$ and specificity as $82.9 \%$ when they used a cut-off level of 13.880, while Çınar et al. ${ }^{[19]}$ obtained a sensitivity level of $72.5 \%$ and a specificity level of $72.3 \%$ using a cut-off value of 10.300 . Considering a cut-off value of $>11.965 / \mathrm{mm}^{3}$, we calculated the sensitivity as $77 \%$, specificity as $81 \%$ (Table 3). Based on these findings, elevated WBC level could be used by clinicians as a parameter to support physical examination and anamnesis findings for the diagnosis of AA in pregnant women.

In AA cases, a characteristic shifting to the left is observed in hemogram due to neutrophilia and lymphopenia. ${ }^{[20,21]}$ Markar et al. ${ }^{[22]}$ and Yavuz et al. ${ }^{[23]}$ reported that NLR had statistically higher diagnostic sensitivity for AA than WBC and CRP. Eren et al., ${ }^{[2]}$ on the other hand, reported that the NLR ratio was higher in patients with complicated appendicitis than in patients subjected to negative appendectomy. This finding was attributed to elevated neutrophilia severity secondary to increased inflammation level and a more evident decrease in lymphopenia. ${ }^{[22]}$ In the present study, the median NLR value observed in patients undergoing appendectomy was 6.00 (I.39-II.04), which was 3.69 (0.75-17.22) in healthy pregnant women. According to these results, the NLR value was significantly higher in patients who were diagnosed with AA and who had appendectomy compared to healthy pregnant women and pregnant women under acute abdominal observation (Table I). Based on multivariate logistic regression analysis using the data obtained in the present study (multinomial logistic regression), NLR was found to be an independent risk factor for the diagnosis of AA (Table 2). The most appropriate cut-off value for NLR was reported as $>3.5$ by Białas et al..$^{[24]}$ and as $\geq 4.5$ by Eren et al. ${ }^{[21]}$ Yavuz et al. ${ }^{[23]}$ calculated a sensitivity level of $92.5 \%$ and a specificity level of $59.3 \%$ for NLR in geriatric patients, when they considered a cut-off value of 3.95 . In all three studies, it was stated that the elevated NLR value was associated with complicated appendicitis. Yazar et al. ${ }^{[4]}$ calculated that for AA diagnosis accuracy rate of NLR was $79.4 \%$ and AUC \pm SE was $0.852 \pm 0.049$ $(p<0.00 \mathrm{I})$ when they used a cut-off value of $>6.84$. On the other hand, Çınar et al. ${ }^{[19]}$ used a cut-off value of $>5.50$ and calculated the sensitivity as $90 \%$, specificity as $89.4 \%$, accuracy rate as $90.8 \%$ and AUC \pm SE value as $0.920 \pm 0.034$ for NLR in AA diagnosis. In the present study, we used a cut-off value of $>5.025$ for NLR, and calculated sensitivity level as $68 \%$ and specificity level as $86 \%$ (Table 3 ). Similar to those reported by Yazar $^{[4]}$ and Çınar, ${ }^{[19]}$ sensitivity and specificity values in the present study were also significant. Based on our findings, elevated NLR level could be used as a supportive parameter to physical examination and anamnesis findings for AA diagnosis in pregnant patients.

Bacterial infections, trauma, malignant neoplasms, burns, tissue infarctions, immunological and inflammatory events and birth are stimuli that cause acute phase response in the body. The purpose of the acute phase response is to neutralize pathogens by isolating them, to reduce tissue damage to a minimum by limiting them, to prevent the generalization of the events, to start the repair, thereby allowing the host hemostatic mechanisms to restore the normal physiological function in a fast manner. ${ }^{[25]} \mathrm{AA}$ causes the initiation of an inflammatory process secondary to bacterial infection in the body, resulting in the formation of an acute phase response by organism against the pathogen. Regardless of the localized or generalized nature of the disease, the acute phase response is a general host reaction. Proteins whose serum or plasma levels change during this response are called acute phase proteins (AFP). Synthesis of AFP proteins occurs in the liver as a result of cytokines released from tissue macrophages, and these proteins reflect nonspecifically the presence and severity of inflammation. ${ }^{[26,27]}$ Proteins whose synthesis increase due to AFY are called positive reactants, while those whose synthesis decrease is termed acute phase reactants. In acute phase response secondary to inflammation in the organism, the amount of CRP increases, whereas the amount of albumin decreases. ${ }^{[26]}$

CRP is an acute phase reactant that starts to increase in the body within 8-12 hours due to the acute phase response caused by inflammation. Its increase is somewhat slower than that of WBC and reaches a maximum level within 24-48 hours. ${ }^{[2]} \mathrm{CRP}$ is an acute phase reactant used quite frequently in the diagnosis of $\mathrm{AA}$, and its sensitivity ranges from $\mathbf{4 0 . 0}$ to $95.6 \%$, and its specificity varies from 53 to $82 \% .{ }^{[27]}$ In many studies examining the relationship between AA and CRP, the CRP level was reported to be especially high in complex appendicitis cases, such as perforation and periapical abscess. [27,29] Using a CRP cut-off level of $20 \mathrm{mg} / \mathrm{L}$, Ayrık et al. ${ }^{[14]} \mathrm{re-}$ ported a sensitivity level of $54.33 \%$ and a specificity level of $56.06 \%$ for CRP in AA cases. On the other hand, Yokoyama et al. ${ }^{[30]}$ found a sensitivity level of $84.3 \%$ and specificity level of $75.8 \%$ using a cut-off value of $49.5 \mathrm{mg} / \mathrm{L}$ for CRP. Yang et al. ${ }^{[31]}$ reported a CRP cut-off value of $24.1 \mathrm{mg} / \mathrm{L}$ for AA cases. There are publications reporting that CRP value increases while the albumin level decreases in the acute phase response secondary to inflammation in pregnant patients. ${ }^{[10,32]}$ Fairclough $^{[10]}$ and Karasahin ${ }^{[1]}$ reported that the combined use of decreased albumin and elevated CRP levels improved the accuracy rate in detecting the acute infection. Both studies 
reported that CAR elevation increased as parallel to the severity of the disease. There are reports showing that elevated CAR levels were associated with aggressive tumor behavior and poor prognosis in oncology patients. ${ }^{[3-35]}$ Qin et al. ${ }^{[10]}$ and Gibson et al. ${ }^{[12]}$ reported that high CAR values reflected the severity of infection in the acute phase of inflammatory bowel disease. Both studies showed that elevated CAR values were associated with the extent and severity of the infection. Goulart ${ }^{[13]}$ stated that increased CAR values could be used as an early marker to determine surgical site infection in cases operated due to colorectal cancer. In the present study, the median CAR value was 10.93 (1.43-76.18) in patients who underwent appendectomy, which was 0.30 (0.04-2.13) in healthy pregnant women. The CAR value was significantly higher in patients who underwent appendectomy after AA diagnosis compared to pregnant women who were under acute abdominal observation or healthy pregnant women (Table I). Multivariate logistic regression analysis (multinomial logistic regression) in the present study indicated CAR as an independent predictor for AA diagnosis (Table 2). Goulart et al. ${ }^{[13]}$ calculated sensitivity and specificity of CAR as $77.3 \%$ and $66.2 \%$, respectively, for identifying the surgical site infection when they used a cut-off value of 43 for CAR. Karaşahin et al. $^{\left[{ }^{\prime \prime}\right]}$ studied infection vulnerability in geriatric patients using a cut-off value of 1.70 for CAR, and they calculated the sensitivity as $74.3 \%$ and specificity $79.6 \%(p<0.00 I)$. In the present study, using a CAR cut-off value of $>2.473$ for AA diagnosis in pregnant patients, we determined the sensitivity and specificity of CAR values to be 96 and $80 \%$, respectively (Table 3). In the study conducted by Goulart et al., high CAR values were because their study included oncology patients and that the measurements were made in the postoperative period. According to these findings, elevated CAR levels could help physicians in the diagnosis of AA in pregnant patients as an additional parameter to support physical examination and anamnesis.

Lymphocytes are involved in immune system regulation and their number increases with inflammation. ${ }^{[36,37]}$ Low lymphocyte number and high CRP level may indicate an infection in the body. Therefore, the combination of lymphocytes and CRP can be used as a biochemical marker to determine the severity of the infection. There are studies reporting that low lymphocyte count and elevated CRP level can be used as an infection marker in orthopedic prosthetic surgeries for an early onset of treatment for the infection. ${ }^{[38,39]}$ Evaluating the data from 554 gastric cancer patients, Okugawa et al. ${ }^{[40]}$ mentioned that low LCR values can be used as a marker to determine surgical site infection. Yazar et al. ${ }^{[4]}$ and Çınar et al. ${ }^{[19]}$ studied pregnant patients and reported that the number of lymphocytes was lower, but CRP was higher in the group of patients who had appendectomy compared to healthy pregnant women. In both studies, the number of lymphocytes decreased while the CRP value increased depending upon the severity of the infection. In the present study, the median LCR value was $0.05(0.004-0.356)$ in patients who underwent appendectomy due to AA and 2.0I (0.38-I I.50) in healthy pregnant women. Decrease in the rate of lymphocytes and an increase in CRP value secondary to infection resulted in a negative correlation between these two parameters. Thus, LCR value was significantly lower in patients who underwent appendectomy after AA diagnosis compared to pregnant women under acute abdominal observation and healthy pregnant women (Table I). Multivariate logistic analysis (multinomial logistic regression) in the present study revealed that LCR was an independent risk factor for the diagnosis of AA in pregnant women patients (Table 2). Using a cut-off value of $<0.127$, LCR could predict AA in pregnant women with an accuracy of $81 \%$, a sensitivity of $73 \%$ and a specificity of $89 \%$ (Table 3). Based on these result, low LCR values could be used by clinicians as support data to physical examination and anamnesis for AA diagnosis in pregnant patients.

Our study carries the limitations inherent in retrospective case studies. In addition, the scarcity of the patients who had appendectomy and exclusion of a small number of patients with complicated appendicitis from the study were the main limitations. Another limitation of this study is the lack of information between the blood withdrawal and the operation time since the inflammatory values may change with time.

\section{Conclusion}

In pregnant patients with suspected AA, WBC, NLR, CAR and LCR could be used as support parameters to the findings from anamnesis, physical examination and imaging methods in the diagnosis. Such a practice could lower the maternal and fetal morbidity/mortality rates and negative laparotomy rates. Our results could contribute and provide valuable insights to limited literature associated with AA in pregnant women. Prospective studies with large cohorts in this area could be useful.

Ethics Committee Approval: Approved by the local ethics committee.

Peer-review: Internally peer-reviewed.

Authorship Contributions: Concept: A.A., M.T., B.O.; Design: A.A., N.A.H., B.O.; Supervision: A.A., Y.A., M.T.; Materials: A.A., B.O.; Data: M.T., B.O.; Analysis: Z.A.K., H.Y.; Literature search: Y.A., M.T., S.M., H.Y.; Writing: A.A., N.A.H.; Critical revision: S.M., H.Y.

\section{Conflict of Interest: None declared.}

Financial Disclosure: The authors declared that this study has received no financial support.

\section{REFERENCES}

1. Zhang Y, Zhao YY, Qiao J, Ye RH. Diagnosis of appendicitis during pregnancy and perinatal outcome in the late pregnancy. Chin Med J (Engl) 2009;122:521-4.

2. Wray CJ, Kao LS, Millas SG, Tsao K, Ko TC. Acute appendicitis: controversies in diagnosis and management. Curr Probl Surg 2013;50:54-86. 
3. Yagci MA, Sezer A, Hatipoglu AR, Coskun I, Hoscoskun Z. Acute appendicitis in pregnancy. Dicle Tip Derg 2010;37:134-139.

4. Yazar FM, Bakacak M, Emre A, Urfalıoglu A, Serin S, Cengiz E, et al. Predictive role of neutrophil-to-lymphocyte and platelet-to-lymphocyte ratios for diagnosis of acute appendicitis during pregnancy. Kaohsiung J Med Sci 2015;31:591-6. [CrossRef]

5. Abbassi-Ghanavati M, Greer LG, Cunningham FG. Pregnancy and laboratory studies: a reference table for clinicians. Obstet Gynecol 2009;114:1326-31. [CrossRef]

6. Franca Neto AH, Amorim MM, Nóbrega BM. Acute appendicitis in pregnancy: literature review. Rev Assoc Med Bras (1992) 2015;61:170-7.

7. İlhan M, İlhan G, Gök AF, Bademler S, Verit Atmaca F, Ertekin C. Evaluation of neutrophil-lymphocyte ratio, platelet-lymphocyte ratio and red blood cell distribution width-platelet ratio as early predictor of acute pancreatitis in pregnancy. J Matern Fetal Neonatal Med 2016;29:1476-80.

8. Daldal E, Akbas A, Dasiran MF, Dagmura H, Bakir H, Okan I. Prognostic importance of neutrophil/lymphocyte and lymphocyte/crp ratio in cases with malignant bowel obstruction. Med Science 2019;8:927-30.

9. Sevgisunar NS, Şahinduran Ş. Hayvanlarda akut faz proteinleri, kullanım amaçları ve klinik önemi. MAKÜ Sag Bil Enst Derg 2014;2:50-72.

10. Qin G, Tu J, Liu L, Luo L, Wu J, Tao L, et al. Serum Albumin and C-Reactive Protein/Albumin Ratio Are Useful Biomarkers of Crohn's Disease Activity. Med Sci Monit 2016;22:4393-400. [CrossRef]

11. Karaşahin Ö, Tosun Taşar P, Timur Ö, Baydar Ö, Yıldırım F, Yıldız F, et al. Palyatif Bakım Alan Geriatrik Hastalarda Enfeksiyon Tanı ve Prognozunda Laboratuvar Belirteçlerin Değeri. Tepecik Eğit ve Araşt Hast Dergisi 2016;26:238-42.

12. Gibson DJ, Hartery K, Doherty J, Nolan J, Keegan D, Byrne K, et al. CRP/Albumin Ratio: An Early Predictor of Steroid Responsiveness in Acute Severe Ulcerative Colitis. J Clin Gastroenterol 2018;52:e48-52.

13. Goulart A, Ferreira C, Estrada A, Nogueira F, Martins S, Mesquita-Rodrigues A, et al. Early inflammatory biomarkers as predictive factors for freedom from infection after colorectal cancer surgery: a prospective cohort study. Surgical infections 2018;19:446-50. [CrossRef]

14. Ayrık C, Karaaslan U, Dağ A, Bozkurt S, Toker İ, Demir F. Lökosit sayısı, yüzde nötrofil oranı ve C-reaktif protein konsantrasyonlarının "kesim değeri” düzeylerinde apandisit tanısındaki değerleri. Ulus Travma Acil Cerrahi Derg 2016;22:76-83.

15. Keskek M, Tez M, Yoldas O, Acar A, Akgul O, Gocmen E, Koc M. Receiver operating characteristic analysis of leukocyte counts in operations for suspected appendicitis. Am J Emerg Med 2008;26:769-72. [CrossRef]

16. Panagiotopoulou IG, Parashar D, Lin R, Antonowicz S, Wells AD, Bajwa FM, Krijgsman B. The diagnostic value of white cell count, C-reactive protein and bilirubin in acute appendicitis and its complications. Ann R Coll Surg Engl 2013;95:215-21. [CrossRef]

17. Yilmaz HG, Akgun Y, Bac B, Celik Y. Acute appendicitis in pregnancyrisk factors associated with principal outcomes: a case control study. Int J Surg 2007;5:192-7. [CrossRef]

18. Körner H, Söndenaa K, Söreide JA. Perforated and non-perforated acute appendicitis-one disease or two entities? Eur J Surg 2001;167:525-30.

19. Çınar H, Aygün A, Derebey M, Tarım İA, Akalın Ç, Büyükakıncak S, et al. Significance of hemogram on diagnosis of acute appendicitis during pregnancy. Ulus Travma Acil Cerrahi Derg 2018;24:423-8. [CrossRef]

20. Andersson RE. Meta-analysis of the clinical and laboratory diagnosis of appendicitis. Br J Surg 2004;91:28-37. [CrossRef]

21. Eren T, Tombalak E, Burcu B, Özdemir İA, Leblebici M, Ziyade S, et al. Akut Apandisit Olgularında Nötrofil/Lenfosit Oranının Tanıda ve
Hastalığın Şiddetini Belirlemedeki Prediktif Değeri. Dicle Tip Derg 2016;43:279-84.

22. Markar S, Karthikesalingam A, Falzon A, Kan Y. The diagnostic value of neutrophil: lymphocyte ratio in adults with suspected acute appendicitis. Acta Chir Bel 2010;110:543-7. [CrossRef]

23. Yavuz E, Erçetin C, Uysal E, Solak S, Biricik A, Yiğitbaş H, et al. Diagnostic Value of Neutrophil/Lymphocyte Ration in Geriatric Cases With Appendicitis. Turkish J Geriatrics 2014;17:345-9.

24. Białas M, Taran K, Gryszkiewicz M, Modzelewski B. Evaluation of neutrophil-lymphocyte ratio usefulness in the diagnosis of appendicitis. Wiad Lek 2006;59:601-6.

25. Uluğ M, Can-Uluğ N, Selek Ş. Akut brusellozlu hastalarda akut faz reaktanlarının düzeyi. Klimik Dergisi 2010;23:48-50. [CrossRef]

26. Yaylı G. İnfeksiyon hastalıklarında C-reaktif protein, sedimantasyon ve lökositler. Ankem Derg 2005;19:80-4.

27. Soylu L, Aydin OU, Ylldı M. Diagnostic value of procalcitonin, C-reactive protein, and erythrocyte sedimentation rate for acute complicated appendicitis. J Clin Anal Medicine 2018;9:47-50. [CrossRef]

28. Wu HP, Lin CY, Chang CF, Chang YJ, Huang CY. Predictive value of $\mathrm{C}$-reactive protein at different cutoff levels in acute appendicitis. Am J Emerg Med 2005;23:449-53. [CrossRef]

29. Shogilev DJ, Duus N, Odom SR, Shapiro NI. Diagnosing appendicitis: evidence-based review of the diagnostic approach in 2014. West J Emerg Med 2014;15:859-71. [CrossRef]

30. Yokoyama S, Takifuji K, Hotta T, Matsuda K, Nasu T, Nakamori M, et al. C-Reactive protein is an independent surgical indication marker for appendicitis: a retrospective study. World J Emerg Surg 2009;4:36.

31. Yang HR, Wang YC, Chung PK, Chen WK, Jeng LB, Chen RJ. Laboratory tests in patients with acute appendicitis. ANZJ Surg 2006;76:71-4.

32. Beyazıt F, Pek E, Türkön H. Serum Ischemia-Modified Albumin Concentration and Ischemia-Modified Albumin/Albumin Ratio in Hyperemesis Gravidarum. Med Bull Haseki 2018;56:292-8. [CrossRef]

33. Yu ST, Zhou Z, Cai Q, Liang F, Han P, Chen R, Huang XM. Prognostic value of the $\mathrm{C}$-reactive protein/albumin ratio in patients with laryngeal squamous cell carcinoma. Onco Targets Ther 2017;10:879-84. [CrossRef]

34. Liu Z, Jin K, Guo M, Long J, Liu L, Liu C, et al. Prognostic Value of the CRP/Alb Ratio, a Novel Inflammation-Based Score in Pancreatic Cancer. Ann Surg Oncol 2017;24:561-8. [CrossRef]

35. Akbas A, Bakir H, Dasiran M, Dagmura H, Ozmen Z, Celtek NY, et al. Significance of Gastric Wall Thickening Detected in Abdominal CT Scan to Predict Gastric Malignancy. J Oncol 2019;2019. [CrossRef]

36. Maurizi G, Della Guardia L, Maurizi A, Poloni A. Adipocytes properties and crosstalk with immune system in obesity-related inflammation.J Cell Physiol 2018;233:88-97. [CrossRef]

37. Ustundag Y, Huysal K, Gecgel SK, Unal D. Relationship between C-reactive protein, systemic immune-inflammation index, and routine hemogram-related inflammatory markers in low-grade inflammation. Int J Med Bioch 2018;1:24-8. [CrossRef]

38. Bekmez Ş, Çağlar Ö, Atilla B. Total kalça artroplastisi sonrası enfeksiyon. TOTBİD Derg 2013;12:268-75. [CrossRef]

39. Smith T. Nutrition: its relationship to orthopedic infections. Orthop Clin North Am 1991;22:373-7.

40. Okugawa Y, Toiyama Y, Yamamoto A, Shigemori T, Ichikawa T, Yin C, et al. Lymphocyte-to-C-reactive protein ratio and score are clinically feasible nutrition-inflammation markers of outcome in patients with gastric cancer. Clin Nutr 2020 39:1209-17. [CrossRef] 


\section{ORİIINAL ÇALIŞMA - ÖZET}

\section{Gebe hastalarda enflamatuvar belirteçlerin akut apandisit tanısı koymadaki değeri \\ Dr. Ahmet Akbaş, ${ }^{1}$ Dr. Zeliha Aydın Kasap, ${ }^{2}$ Dr. Nadir Adnan Hacım, ${ }^{1}$ Dr. Merve Tokoçin, ${ }^{1}$ Dr. Yüksel Altınel, ${ }^{1}$ Dr. Hakan Yigitbaş, ${ }^{1}$ Dr. Serhat Meriç1, Dr. Bakiye Okumuş ${ }^{3}$}

${ }^{1}$ Sağlık Bilimleri Üniversitesi, İstanbul Bagcılar Eğitim ve Araştırma Hastanesi, Genel Cerrahi Kliniği, İstanbul

${ }^{2}$ Karadeniz Teknik Üniversitesi Tıp Fakültesi, Biyoistatistik ve Tip Bilişimi Anabilim Dalı, Trabzon

j̇stinye Üniversitesi Tıp Fakültesi, Kadın Hastalıkları ve Doğum Anabilim Dalı, İzmir

AMAÇ: Gebelik esnasında en sık obstetrik dışı cerrahi müdahaleye neden olan hastalık akut apandisittir (AA). AA tanısı laboratuvar testleri eşliğinde anamnez ve fizik muayene ile birlikte konulmaktadır. Gebelikte gözlenen fizyolojik ve anatomik değişiklikler nedeni ile AA tanısı gebe olmayan hastalara göre daha zordur. Bu çalışmada, hamilelik esnasında AA tanısında beyaz küre (WBC), nötrofil/lenfosit oranı (NLR), CRP/albümin oranı (CAR) ve lenfosit/CRP oranı (LCR) önemini araştırdık.

GEREÇ VE YÖNTEM: Çalışmada, Eylül 20I5-Aralık 2019 yıları arasında genel cerrahi kliniğinde AA ön tanısı ile yatışı yapılarak takibi yapılan gebe hastalar "International Statistical Classification of Diseases and Related Health Problems-I0" (ICD-I0) tanı kodu kullanilarak retrospektif olarak belirlendi. Hastalar iki gruba ayrılarak I. Gruba AA nedeni ile apendektomi uygulanan, patolojik değerlendirme sonucuna göre süpüratif apandisit tanısı konulan hastalar, II. Gruba AA ön tanısı ile yatırılan ve takiplerinde ameliyat edilmeden şifa ile taburcu edilen gebe hastalar dahil edildi. Kontrol grubuna (Grup III) ise hastanemiz kadın doğum polikliniğinde takibi yapılan çalışma kriterlerine uygun, rastgele seçilmiş, çalışmaya katılmayı kabul eden 32 sağlıklı gebe prospektif olarak belirlenerek dahil edildi.

BULGULAR: Çalışmaya, yaş ortalaması $29.20 \pm 4.47$ olan 96 gebe hasta (32 sağlıklı gebe, 32 akut batın müşahede ile takip edilen gebe, 32 apendektomi uygulanmış gebe) alındı. Bu hastalardan ameliyat ve histopatolojik bulgulara göre süpüratif apandisit olmayan üç olgu (negatif apendektomi) ile perfore apandisit tespit edilen iki olgu çalışma dışı bırakıldı. Yapılan değerlendirmelerde Grup I oluşturan hastaların WBC değeri $(p=0.00$ I), $C A R$ değeri $(p=0.00 \mathrm{I})$, NLR değeri $(p=0.00 \mathrm{I})$ grup II ve III'den anlamlı düzeyde yüksek iken, LCR değerinin düşük olduğu gözlendi $(p=0.00 \mathrm{I})$. Yapılan çok değişkenli lojistik regresyon analizine göre; WBC, CAR, NLR yüksekliği ile LCR düşüklüğü gebe hastalarda AA tanısında bağımsız değişken olduğu gözlendi.

TARTIŞMA: Tıbbi öykü, fizik muayene ve görüntüleme tekniklerine ek olarak, gebe kadınlarda AA tanısı için WBC, NLR, CAR ve LCR değerlerinin göz önünde bulundurulması klinisyene karar vermede kolaylık sağlayabilir.

Anahtar sözcükler: Akut apandisit; CRP albümin oranı; gebelik; lenfosit; nötrofil.

Ulus Travma Acil Cerrahi Derg 2020;26(5):769-776 doi: 10.14744/tjtes.2020.03456 